\title{
PERANCANGAN SISTEM INFORMASI PERHITUNGAN INSENTIF (BONUS) SALES CONSULTAN/COUNTER PADA PT. LAUTAN BERLIAN UTAMA MOTOR PADA MITSUBISHI MOTOR
}

\author{
Dian Gustina, Samsiah \\ Universitas Persada Indonesia Y.A.I \\ dgustina77@gmail.com
}

\begin{abstract}
In the current era of globalization, information technology is very important to support the smooth activities of an organization which is a means of information and communication that is useful in the right and accurate decision making process. At present there are still many companies that use manual systems in calculating sales bonuses / counter incentives and recording their administration manually, such as employee data, employee sales data, and employee bonus data. One company that still adheres to this system is PT. Lautan Berlian Utama Motor. To minimize the occurrence of errors in the calculation process of sales incentives consultants / counters the author conducted research to design an information system for calculating incentive (bonus) sales consultants / counters at PT. Lautan Berlian Utama Motor. Data collection method is done by observation, interview, literature study. With this sales incentive calculation information system design application, it is expected to accelerate the operational activities process with interested parties in the sales incentive calculation process can run well.
\end{abstract}

Keyword: System, Information, car sales, incentive, incentive report, My Sql.

ABSTRAKSI
Di era globalisasi saat ini teknologi informasi sangat penting untuk menunjang kelancaran aktivitas suatu organisasi yang dimana hal tersebut merupakan sarana informasi dan komunikasi yang berguna dalam proses pengambilan keputusan yang tepat dan akurat. Saat ini masih banyak perusahaan yang menggunakan sistem manual dalam menghitung insentif (bonus) sales consultan/counter dan pencatatan administasrinya di catat secara manual, seperti data pegawai, data penjualan pegawai, dan data bonus pegawai. Salah satu perusahaan yang masih menganut sistem ini adalah PT. Lautan Berlian Utama Motor. Untuk memimalisis terjadinya kesalahan dalam proses perhitungan insentif sales consultan/counter penulis melakukan penelitian untuk merancang suatu sistem informasi perhitungan insentif (bonus) sales consultan/counter pada PT. Lautan Berlian Utama Motor. Metode pengumpulan data dilakukan dengan observasi, wawancara, studi pustaka. Dengan adanya aplikasi perancangan sistem informasi perhitungan insentif sales ini di harapkan dapat mempercepat proses kegiatan operasional dengan pihak-pihak yang berkepentingan dalam proses perhitungan insentif (bonus) sales dapat berjalan dengan baik.

Kata kunci: Sistem, Informasi, penjualan mobil, bonus, laporan bonus, My Sql. 


\section{PENDAHULUAN}

\section{Latar Belakang Masalah}

Sejalan dengan perkembangan ilmu dan teknologi dewasa ini, semakin banyak perusahaan atau instansi yang bermunculan. Pada masa sekarang, suatu perusahaan sebaiknya dapat bekerja dengan cepat tepat dan benar dengan tingkat ketelitian yang tinggi agar dapat terus berjalan dan bertahan dalm persaingan yang kompetitif. Sistem informasi yang dibutuhkan juga harus akurat, tepat waktu dan fleksibel. Hal ini akan menunjang kelancaran aktivitas di perusahaan atau instansi dalam kegiatan sehari-harinya.

Saat ini masih banyak perusahaan yang menggunakan sistem manual dalam menghitung insentif (bonus) karyawan dan pengelolaan administrasinya pun masih dicatat kedalam kertas secara manual. Misalnya data pegawai, data penjualan pegawai, dan data bonus pegawai. Salah satu perusahaan yang masih menganut sistem ini adalah PT. Lautan Berlian Utama Motor. Hal tersebut dapat dilihat dari proses penghitungan insentif Sales Consultan/Counter yang terjadi sehari hari masih dicatat dalam buku atau lembaran dokumen. Dalam proses manual tersebut sering terjadi kesalahan dalam perhitungan insentif Sales Consultan, kesulitan dalam pencarian data dan lain sebagainya.

PT. Lautan Berlian Utama Motor adalah perusahaan yang bergerak dibidang jasa dan penjualan, dimana pada saat pelaksanaan kegiatan usahanya menggunakan jasa Sales Consultan/Counter untuk membuat daya tarik penjulan. PT. Lautan Utama Motor membutuhkan sesekali adanya penataan pelaksanaan administrasi yang efektif dan efisien serta terencana dalam hal perhitungan insentif Sales
Consultan/Counter demi menunjang dan memberikan pelayanan yang dengan hasil kerja yang dapat dipertanggung jawabkan. Semua dijalankan agar kedua belah pihak yang saling berkaitan dapat menjalin kerjasama yang saling menguntungkan. Untuk itulah penulis mencoba merancang sebuah sistem mengenai pelaksanaan kegiatan akuntansi (Administrasi) perhitungan insentif Sales Consultan/Counter terhadap efisiensi kerja.

Memuaskan untuk Sales Consultan/Counter, sehingga para Sales mendapatkan hasil yang sesuai dengan apa yang mereka kerjakan. Di dalam pelaksanaannya, masih sering dijumpai hal - hal yang menghambat kelancaran administrasi perhitungan insentif terhadap Sales Consultan/ Counter. Pengarsipan data - data (invoice) yang masih tidak tersusun dengan baik, ketersediaan dana operasional perusahaan serta kurangnya sumber daya manusia dalam penerapan proses perhitungan dengan menggunakan system. Kejadian seperti itu akan berpengaruh kepada kelancaran produksi, sehingga menjadikan pekerjaan itu kurang efisien dan efisien.

Berdasarkan latar belakang tersebut, maka penulis memilih judul "Perancangan Sistem Informasi Perhitungan Insentif (Bonus) Sales Consultan/Counter Pada PT. Lautan Berlian Utama Motor (Mitsubishi Motor)". Dengan menggunakan bahasa pemrograman PHP dan MySQL.

\section{Perumusan Masalah}

Dilihat dari latar belakang yang dibahas sebelumnya, penulis merumuskan beberapa masalah yaitu mengenai :

1. Proses perhitungan insentif sales consultan pada PT. Lautan Berlian 
Utama Motor masih dilakukan secara manual, dengan cara menghitung satu-persatu sihingga sering terjadi keterlambatan dalam melakukan pembayaran insentif sales consultan.

2. PT. Lautan Berlian Utama Motor masih kesulitan dalam mendapatkan data sales consultan dan penjualan sales consultan sehari-hari, sehingga dapat menghambat petugas admin dalam melakukan penghitungan insentif

\section{Pembatasan Masalah}

Dalam penulisan tugas akhir ini penulis melakukan pembatasan masalah agar objek penelitian dapat terarah sesuai dengan apa yang penulis maksudkan :

1. Dalam pembuatan tugas akhir ini penulis hanya membahas mengenai perhitungan insentif sales consultan pada PT. Lautan Berlian Utama Motor.

2. Sistem informasi yang akan dibangun hanya dapat digunakan pada PT. Lautan Berlian Utama Motor.

\section{Tujuan Penulisan}

Tujuan dari penulisan ini adalah untuk membuat sistem informasi yang berbasiskan web yang diharapkan dapat membantu perusahaan dalam melakukan penghitungan insentif sales consultan.

\section{Metodologi Penelitian}

Metodologi yang penulis lakukan dalam mengerjakan tugas akhir ini adalah sebagai berikut:

Metode Pengumpulan Data
a. Observasi
b. Wawancara
c. Studi Pustaka

Metode Pengembangan Sistem

Metodologi yang digunakan dalam penulisan tugas akhir ini adalah
WDLC/Web Development Life Cycle (Van Duyne, D. K., Landay, J. A., \& Hong, J. I.) adapun tahapannya adalah sebagai berikut :

1. Analisis

Pada tahapan analisis penulis menentukan berbagai kebutuhan (requirement) apa yang dibutuhkan dari website yang akan dibangun dan juga perangkat (tools) yang digunakan.

2. Penentuan Spesifikasi

Pada tahap ini bertujuan untuk membuat spesifikasi secara rinci tentang arsitektur proyek, gaya dan kebutuhan material untuk proyek.

3. Struktur Situs dan Desain

Pada tahap ini penulis membuat sketsa desain, menganalisis hasil desain, menentukan konten dan merancang database.

4. Pengembangan

Pada tahap ini dilakukan pembuatan berkas dan pemograman dari sistem website.

5. Pengujian

Pada tahap ini dilakukan pengujian terhadap website yang telah dibuat.

6. Pemasaran

Pada tahap ini dilakukan pemasaran terhadap website yang dibuat.

7. Pemeliharaan

Pada tahap pemeliharaan ini adalah menemukan kesalahan atau gangguan setelah website di implementasikan.

\section{Pengertian Sistem}

Sistem adalah suatu kumpulan atau himpunan dari unsur, komponen atau variabel-variabel yang terorganisasi, saling berinteraksi, saling tergantung satu sama lain dan terpadu Menurut Tata Sutabri (2004:3).

\section{Pengetian Informasi}


Sistem informasi adalah suatu sistem didalam suatu organisasi yang mempertemukan kebutuhan pengolahan transaksi harian yang mendukung fungsi operasi organisasi yang bersifat manajerial dengan kegiatan strategi dari organisasi untuk dapat menyediakan kepada pihak luar tertentu dengan laporan-laporan yang diperlukan (Tata Sutabri 2004)

\section{PEMBAHASAN}

Analisis

Sistem yang sedang berjalan adalah sebagai berikut :

a. Sales Consultant/Counter mengisi form pengajuan insentif, pengajuan tersebut berisikan data absensi dan data pengajuan pejualan mobil.

b. Sales Consultant/Counter mengajukan insentif tersebut kepada admin sales, dengan kondisi sampai pada target yang telah di capai, piutang customer telah lunas atau telah di beli.

c. Admin sales mengecek kembali data pengajuan tersebut jika sudah sesuai target dan piutang sudah dibayarkan, maka lanjut untuk untuk di ttd oleh bagian admin sales.

d. Admin sales mencetak data pengajuan yang telah di ttd dan informasi total piutang yg sudah di bayar, kemudian admin sales menyerahkan data tersebut kepada bagian Accounting.

e. Bagian Accounting mengecek kembali dan menyimpan data pengajuan tersebut, kemudian di berikan kepada Operational Head untuk di ttd dan di buatkan tanda pencairan insentif.

f. Insentif di terima oleh sales.

Kelemahan - kelemahan dari sistem perhitungan insentif yang sedang berjalan :
1. Tidak tersedianya sistem pengolahan data penjualan yang terkomputerisasi dan diakses secara mudah.

2. Perhitungan insentif kepada karyawan hanya di dikerjakan oleh satu orang admin staff di PT. Lautan Berlian Utama Motor, sehingga admin staff tersebut merasa kewalahan dalam mengurus insentif untuk seluruh karyawan sehingga dapat menghambat dalam proses perhitungan dan pencairan insentif.

3. Dalam proses perhitungan insentif karyawan, admin staff masih menggunakan program aplikasi microsoft excel. Ketika admin staff salah dalam mengisi sebuah data maka akan menghasilkan data yang tidak sesuai dengan standar yang telah di tetapkan perusahaan. Dan proses yang berulang-ulang sehingga terasa lambat.

Solusi untuk mengatasi permasalahan tersebut, antara lain :

1) Membangun Sistem Informasi Perhitungan Insentif (Bonus) Sales Consultan/Counter yang terkomputerisasi sebagai solusi alternatif baru dalam melakukan proses perhitungan insentif pada PT. Lautan Berlian Utama Motor yang diharapkan dapat memberikan efisiensi waktu transaksi kepada para karyawan dan dapat meningkatkan efektivitas kerja para karyawan

2) Membuat media penyampaian informasi yang terkomputerisasi agar dapat memberikan informasi kepada admin staff dan manager finance tentang Laporan Penjualan dan performance sales, data Product dan data karyawan.

\section{Perancangan yang diusulkan}

Tahap perancangan sistem yang digambarkan sebagai perancangan untuk 
membangun suatu sistem dan mengkonfigurasikan komponenkomponen perangkat lunak dan perangkat keras sehingga menghasilkan sistem yang baik, sistem yang dirancang tersebut menjadi satu komponen. Tahapan perancangan prosedur ini akan dijelaskan dengan menggunakan pemodelan sistem informasi berorientasi objek dengan UML.
Use Case Diagram

Use Case diagram adalah model fungsional sebuah sistem yang menggunakan actor dan use case. Use Case adalah layanan (service) atau fungsi - fungsi yang disediakan oleh sistem untuk pengguna - penggunanya. Use Case Diagram dibuat untuk memvisualisasikan / menggambarkan hubungan antara Actor dan Use Case. Use Case diagram mempresentasikan kegunaan atau fungsi - fungsi sistem dari perspektif pengguna.

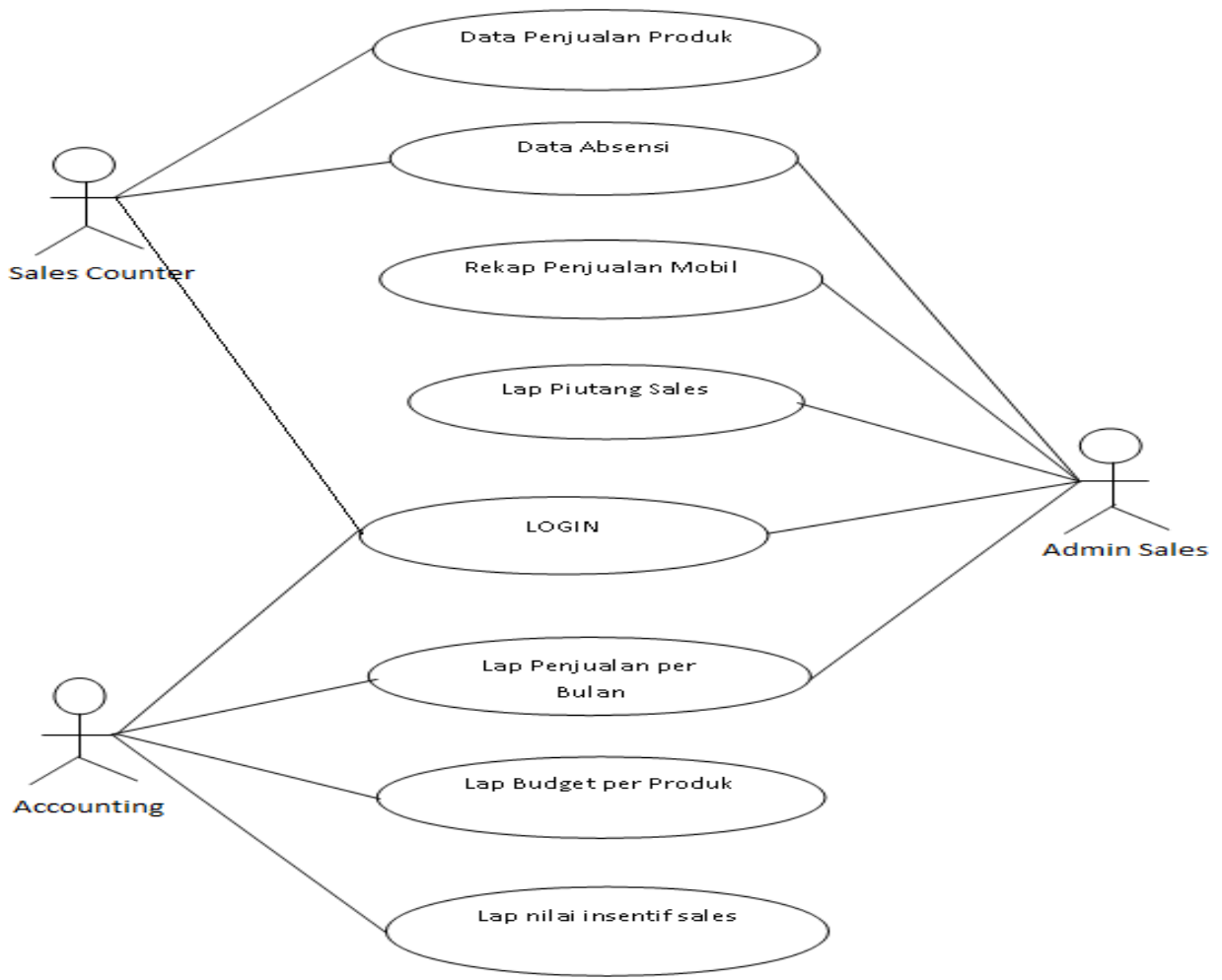

Gambar 3.2. Use Case Diagram yang diusulkan.

\section{Activity Diagram}

Activity diagram (diagram aktivitas) adalah diagram yang menggambarkan aliran fungsionalitas dari sistem. Pada tahap pemodelan bisnis, diagram aktivitas dapat digunakan untuk menunjukkan aliran kerja bisnis (business work flow). Dapat juga digunakan untuk menggambarkan aliran kejadian (flow of event). 


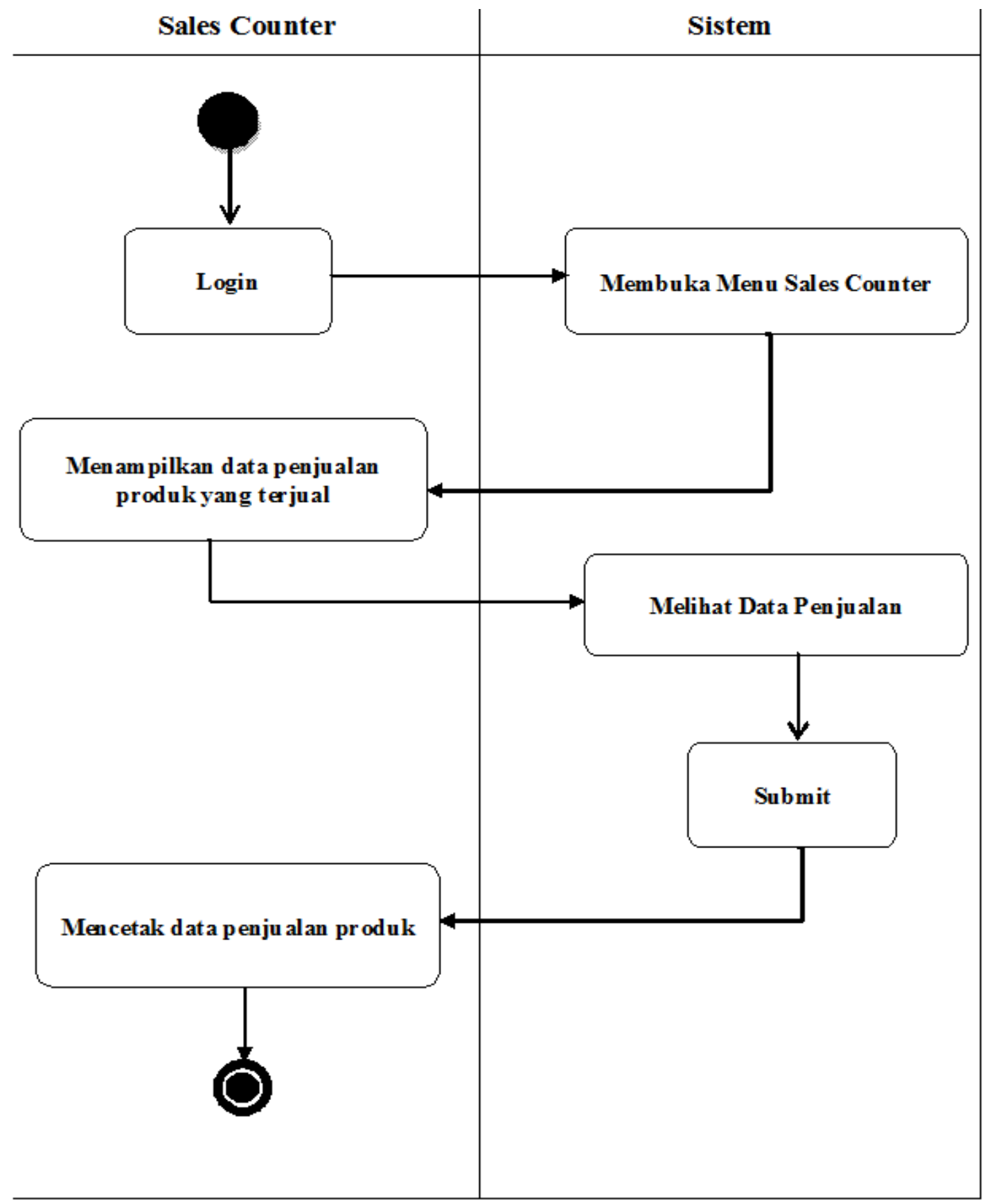

Gambar 3.3. Activity Diagram Data Penjualan Produk Sistem Informasi pada Sales Consultant/Counter yang diusulkan. 


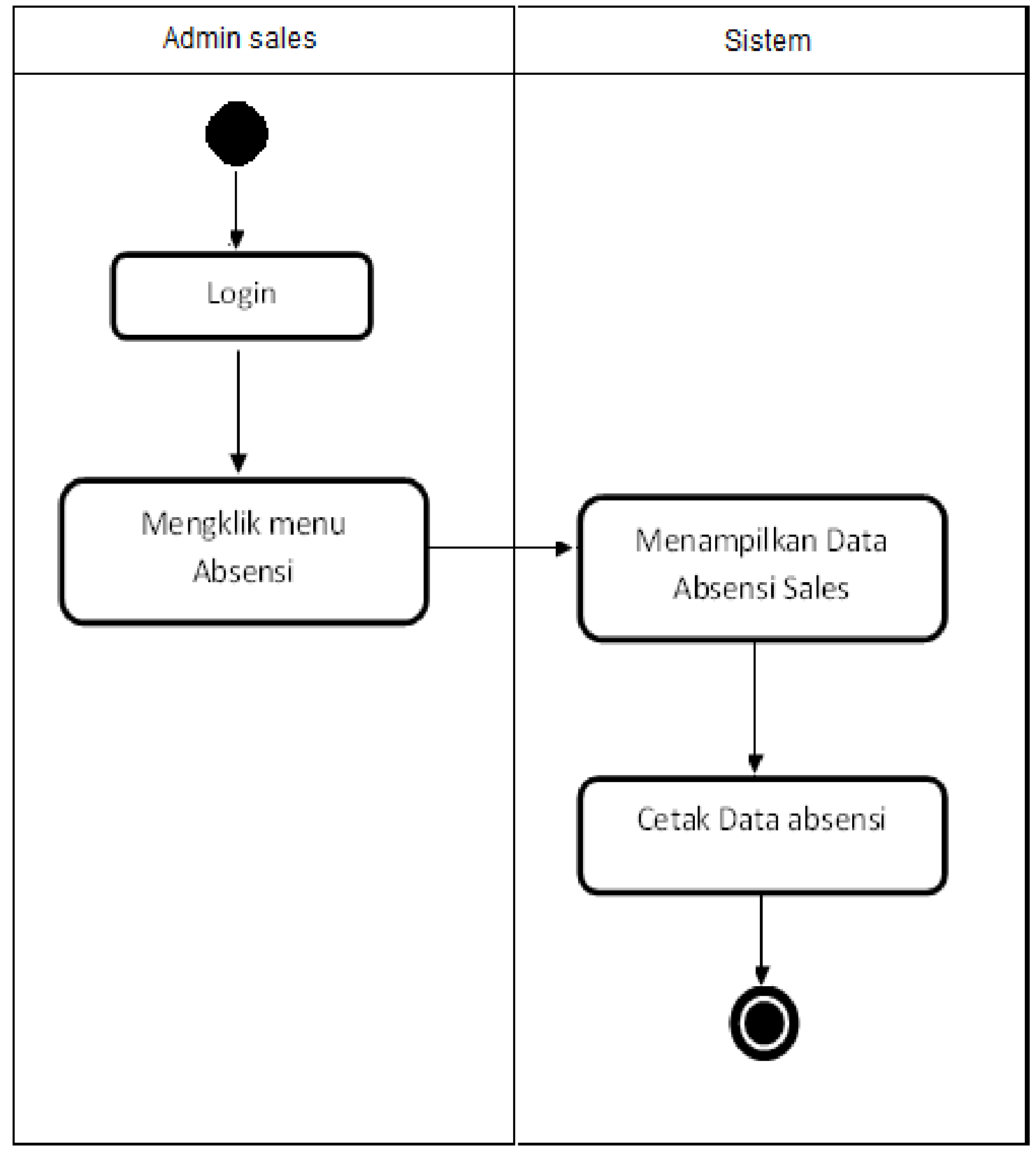

Gambar 3.4. Activity Diagram Data Absensi pada Sistem Informasi pada Sales Consultant/Counter yang diusulkan. 


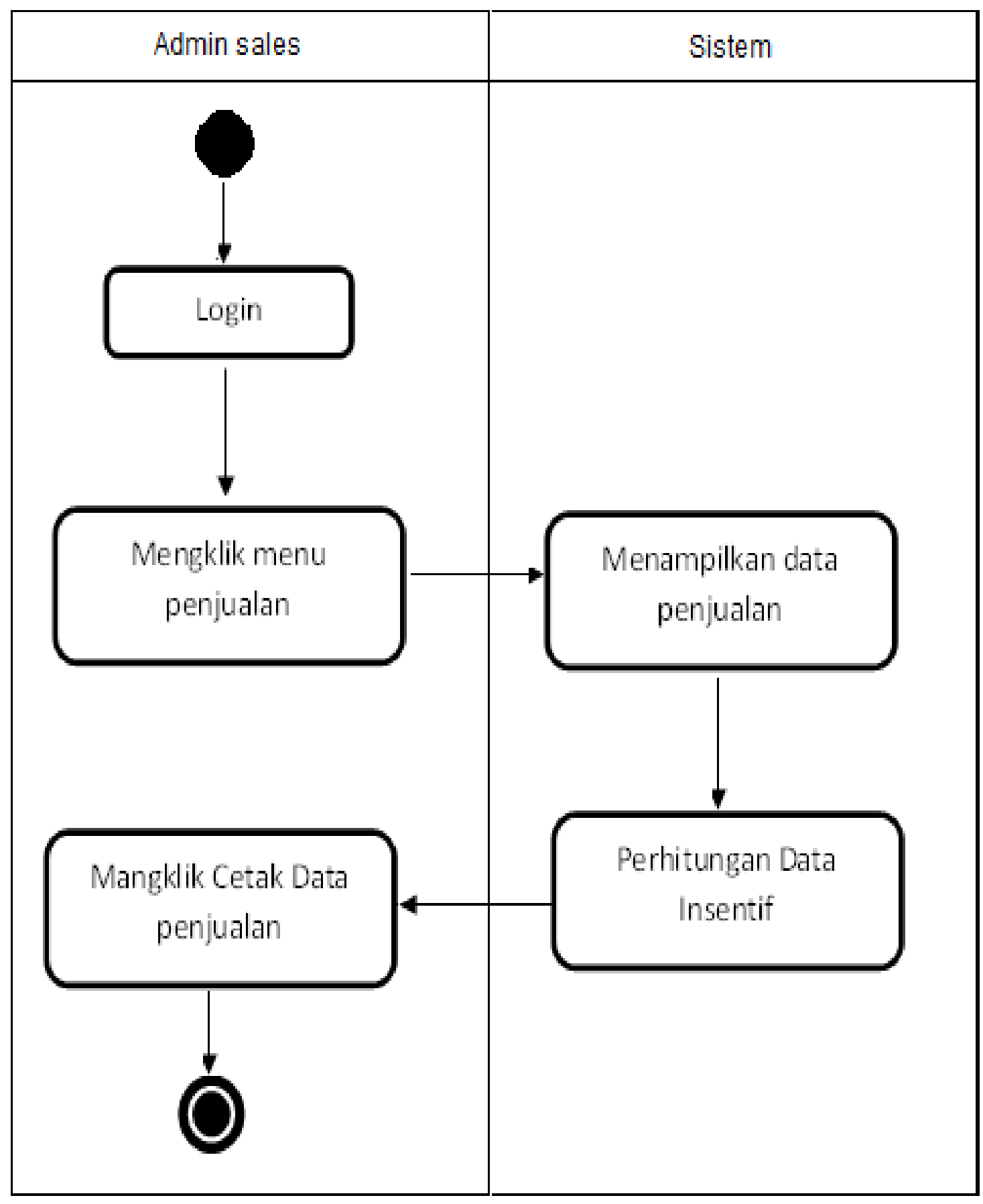

Gambar 3.5. Activity Diagram Rekap Penjualan pada Sistem Informasi pada Sales Consultant/Counter yang diusulkan. 


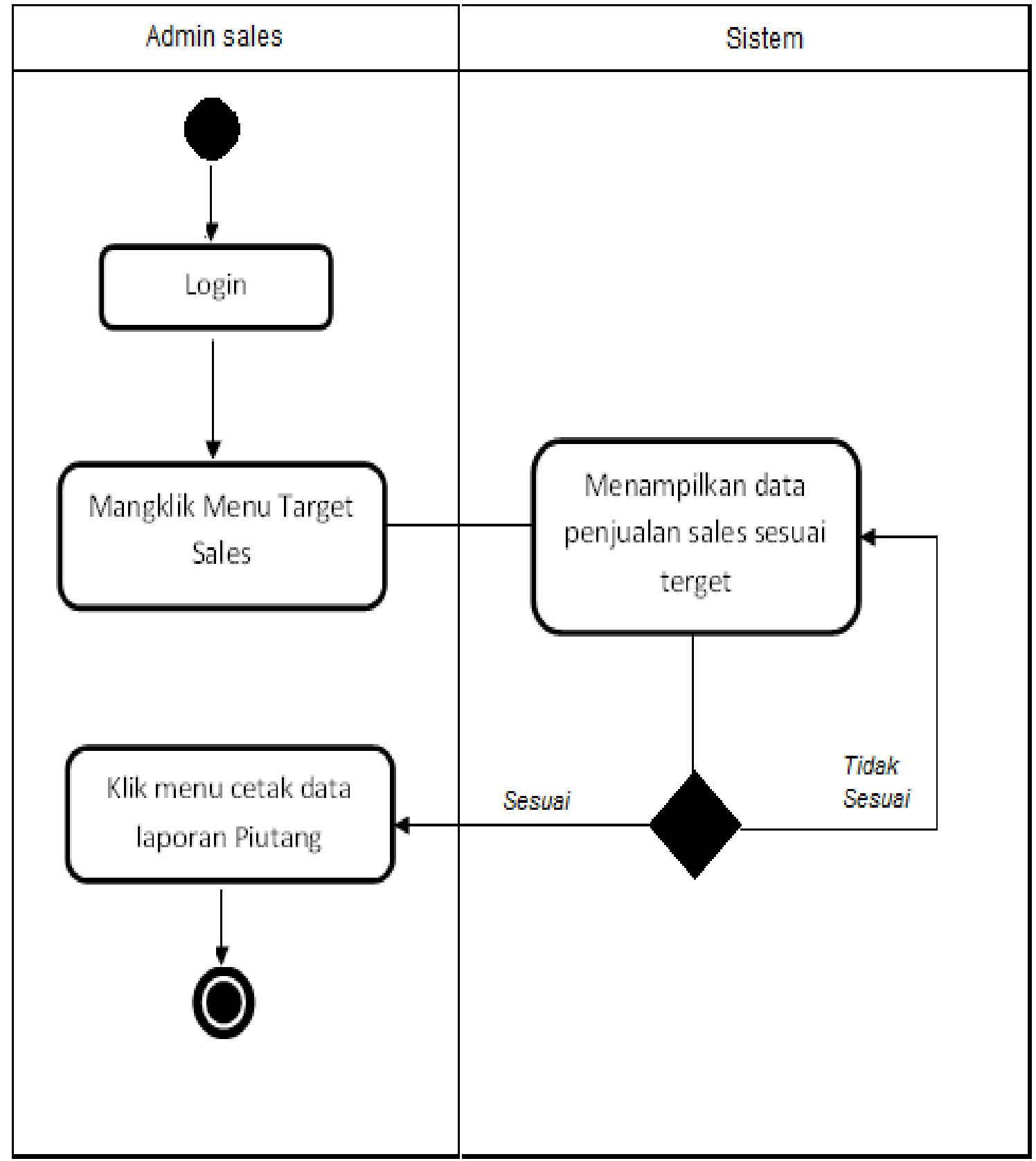

Gambar 3.6. Activity Diagram Laporan Piutang pada Sistem Informasi pada Sales Consultant/Counter yang diusulkan. 


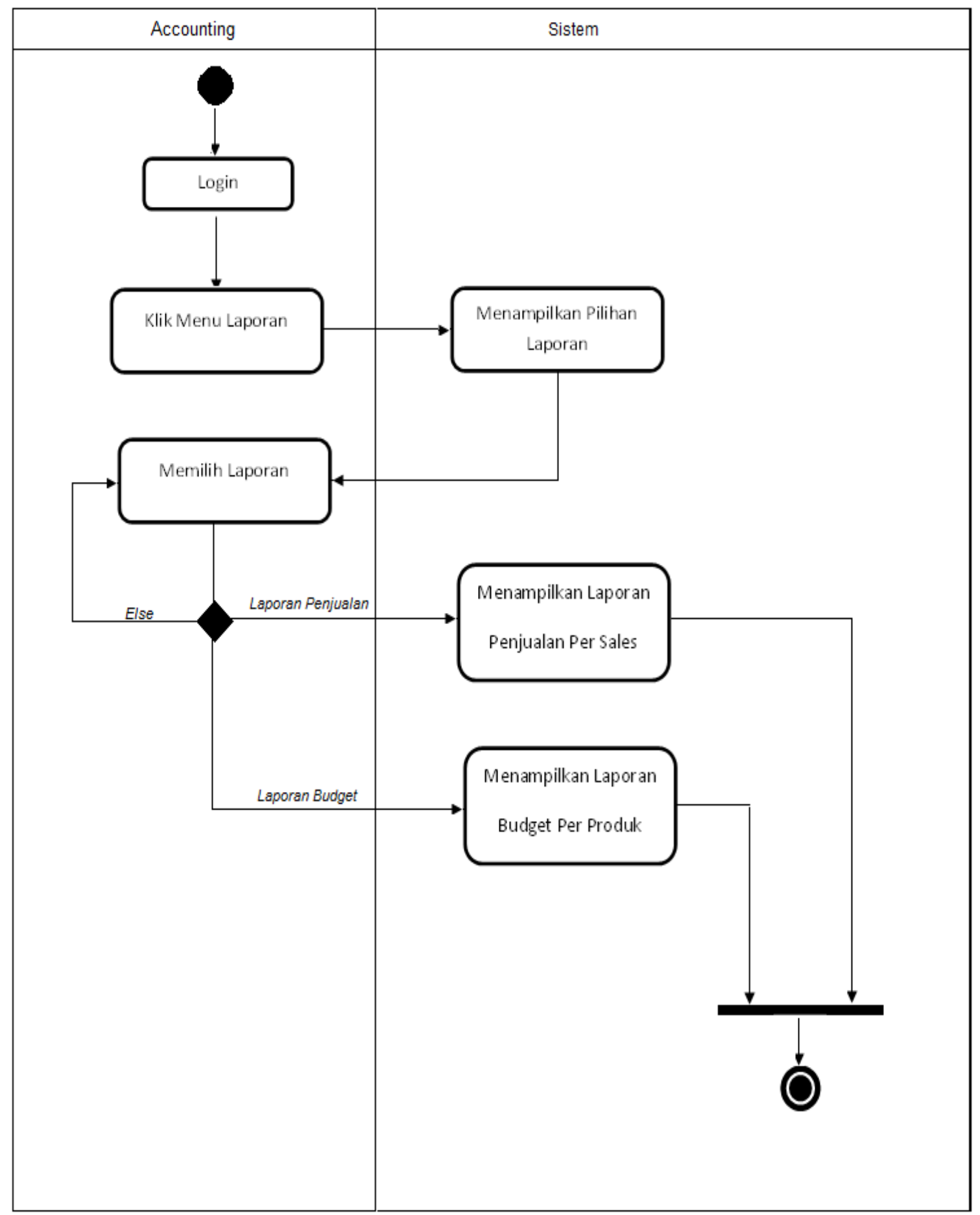

Gambar 3.7. Activity Diagram Laporan Sistem Informasi Perhitungan Insentif (Bonus) Sales Consultant/Counter Yang Diusulkan. 


\section{Sequence Diagram}

Sequence Diagram digunakan untuk menggambarkan interaksi antar objek dalam waktu yang berurutan. Tetapi pada dasarnya sequence Diagram selain digunakan dalam lapisan abstraksi model objek. Kegunaannya untuk menunjukkan rangkaian pesan yang dikirim antara object juga interaksi antara objek, sesuatu yang terjadi pada titik tertentu dalam eksekusi sistem. Komponen utama sequence diagram terdiri atas objek yang dituliskan dengan kotak segiempat bernama pesan diwakili oleh garis dengan tanda panah dan waktu yang ditunjukkan dengan proses vertikal. Berikut adalah sequence diagram yang diusulkan pada sistem pehitungan insentif (bonus) Sales Consultant/Counter, yaitu:
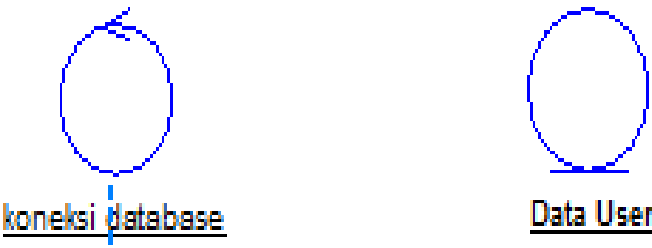

Data User

\section{Sales Counter}
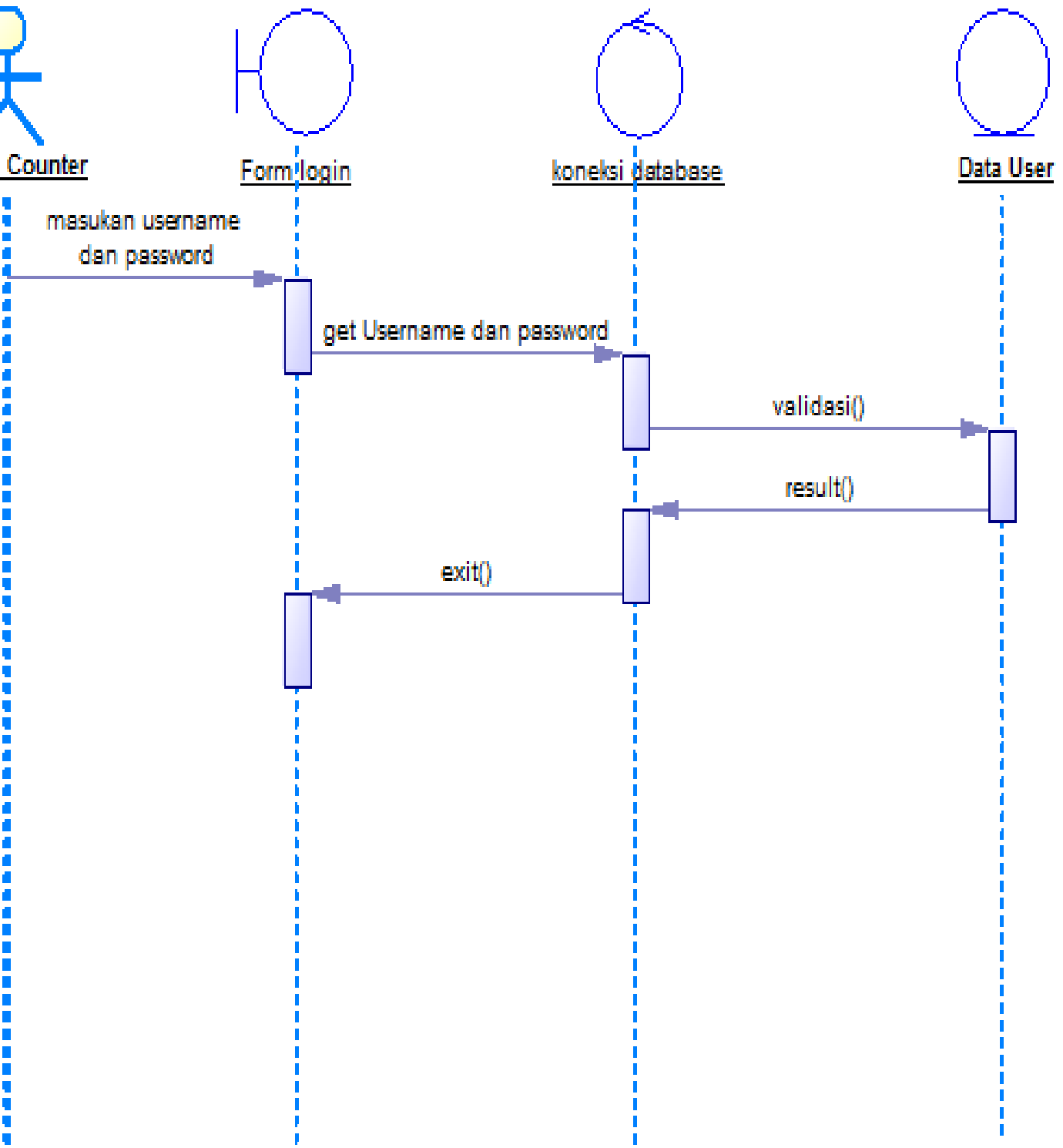

Gambar 3.8. Sequence Diagram Login Sales Counter 


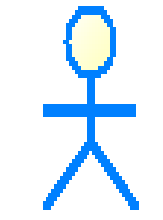

Admin Sales

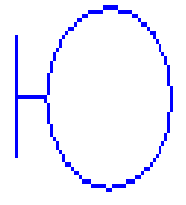

Formilogin

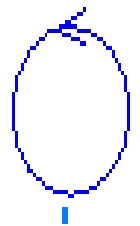

konelki database

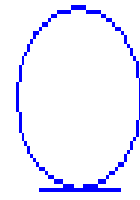

Data User

masukan usenname dan password

get Username dan password

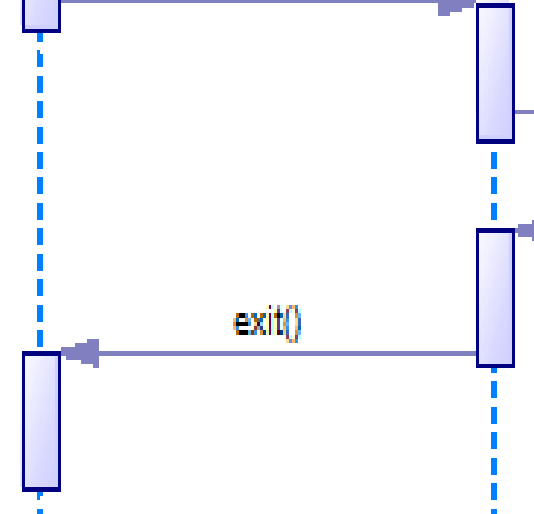

validasi(

1

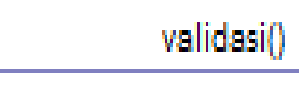

Gambar 3.9. Sequence Diagram Login Admin Sales 


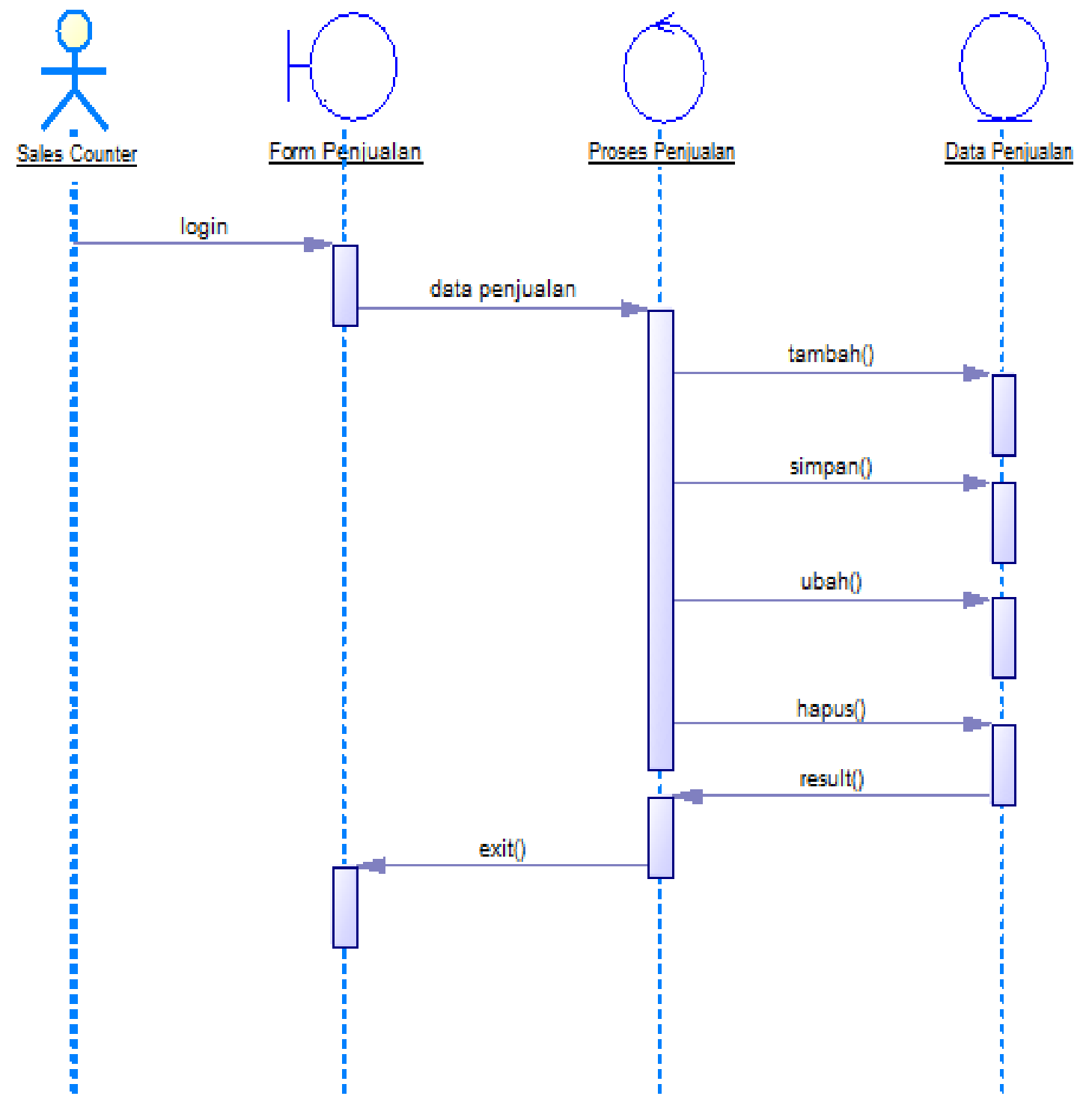

Gambar 3.10. Sequence Diagram Penjualan 


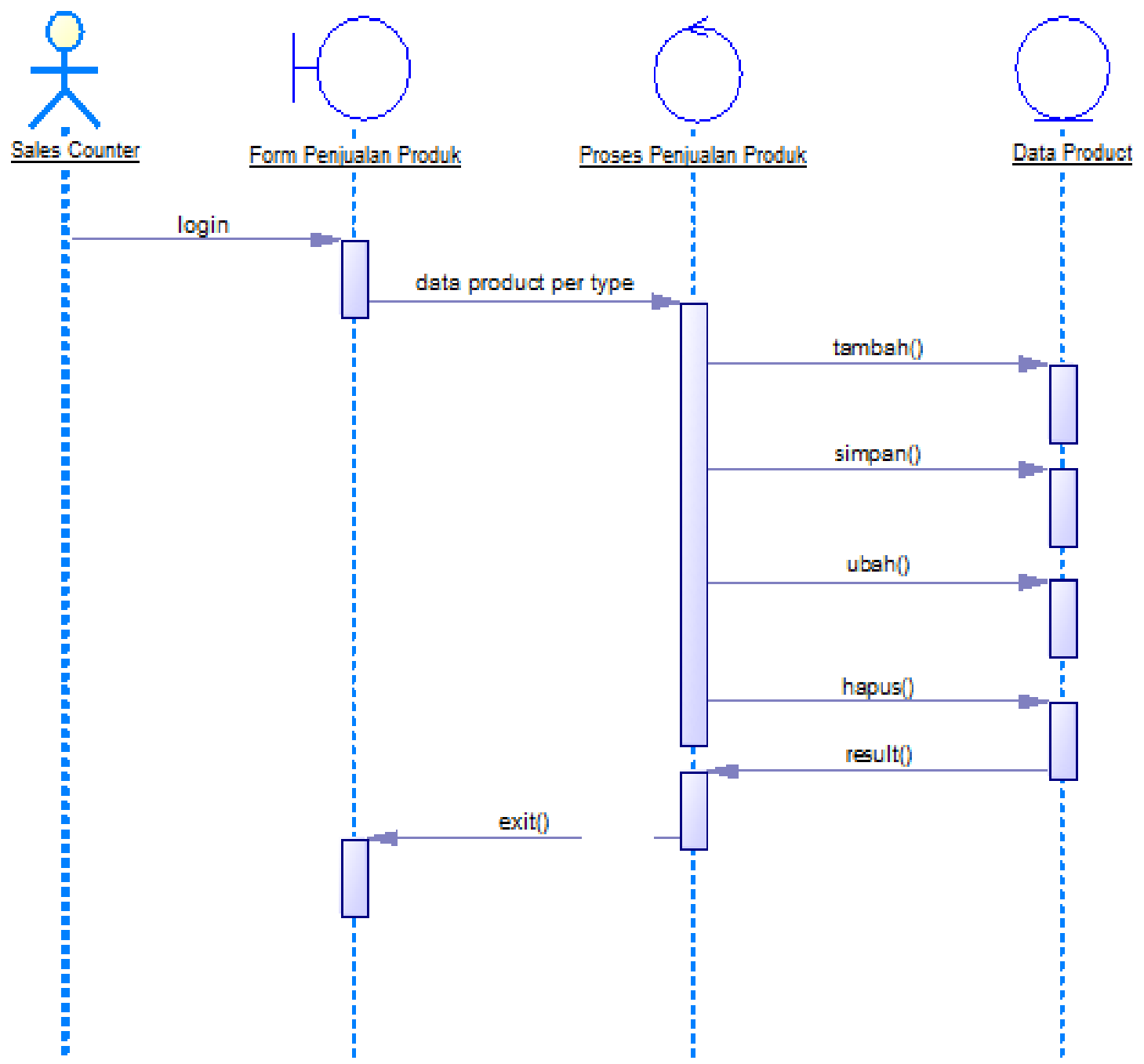

Gambar 3.11. Diagram Sequence Data Penjualan Produk 


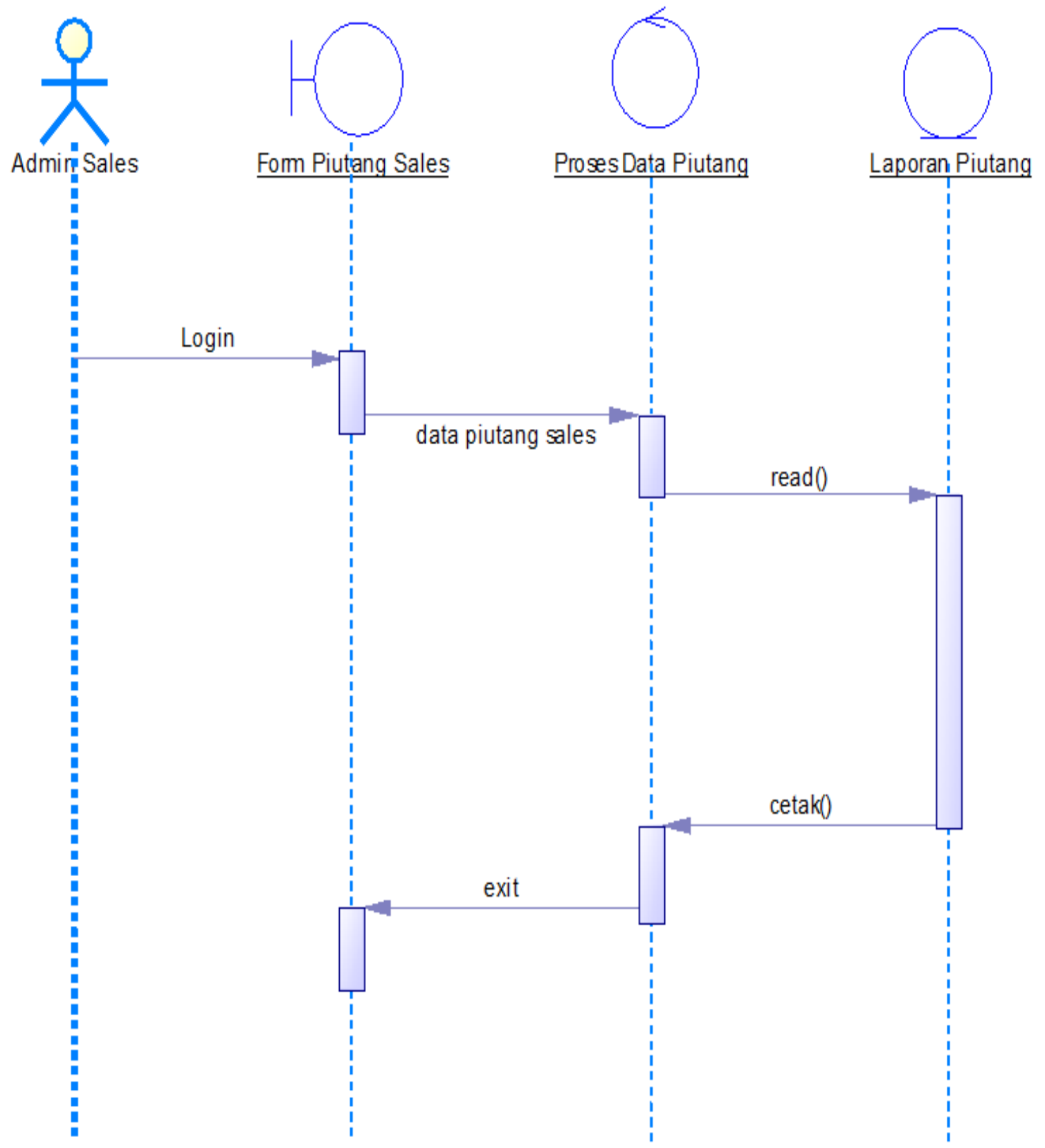

Gambar 3.12. Diagram Sequance Laporan Piutang 


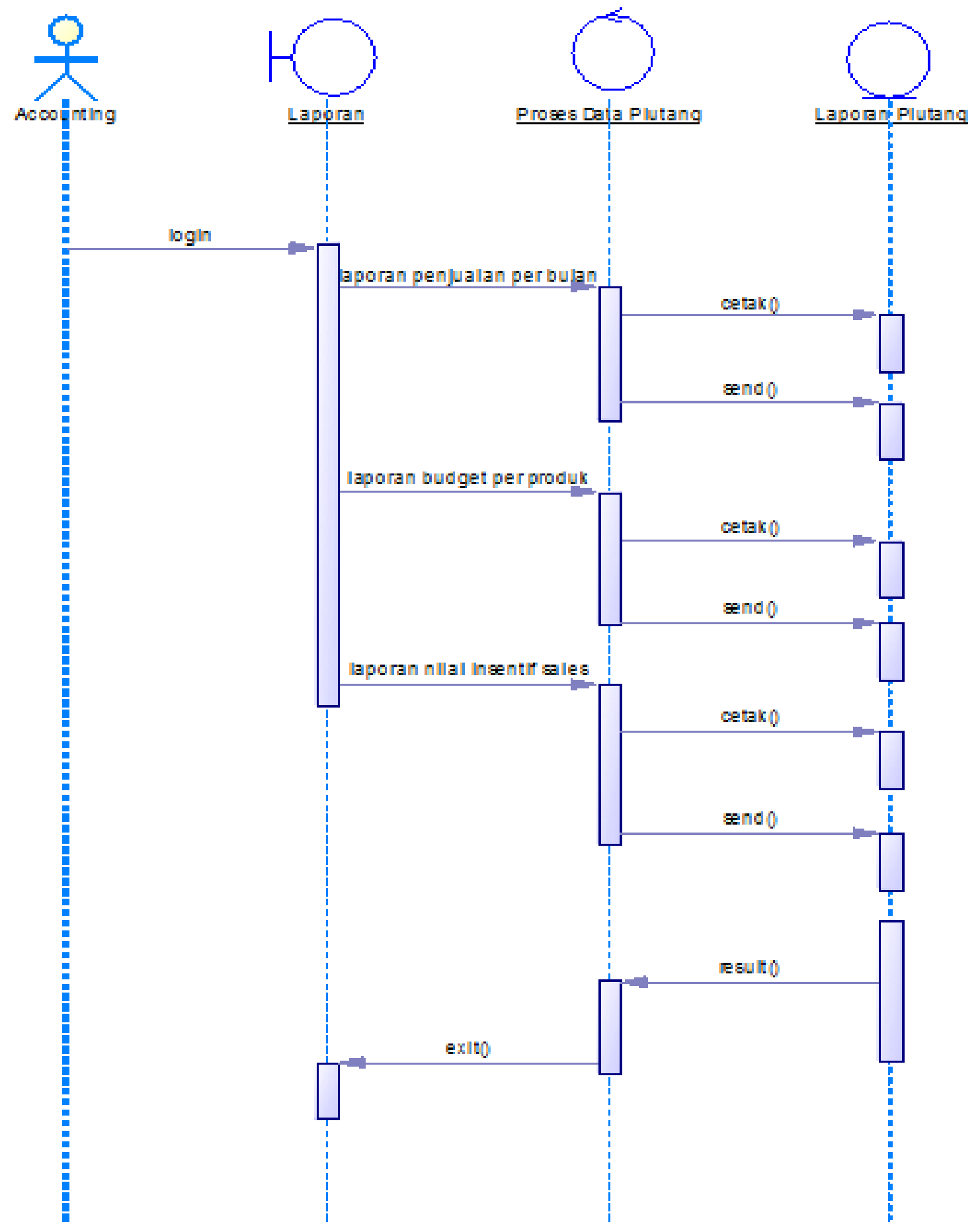

Gambar 3.13. Diagram Sequence Laporan Accounting

\section{Class Diagram}

Menggambarkan struktur statis class di dalam sistem. Class mempresentasikan sesuatu yang ditangani oleh sistem.Dengan melihat karakteristik sistem pemasaran produk dari payroll staff beserta proses - proses yang terjadi, maka dapat dibuat Class Diagram Berikut Class Diagram Sistem Informasi Penjualan pada PT. Lautan Berlian Utama Motor. 


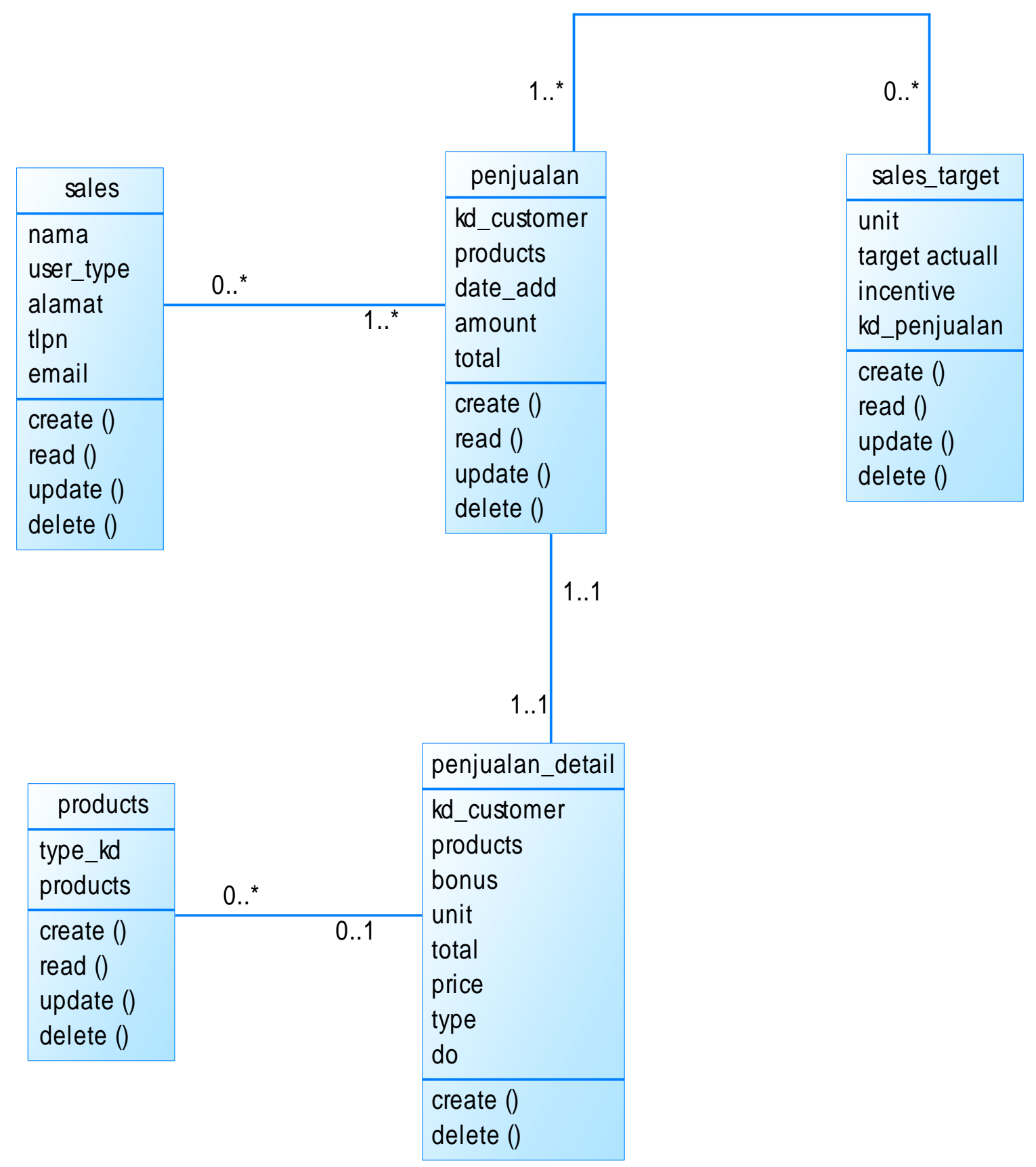

Gambar 3.14. Class Diagram Perhitungan Insentif (Bonus) Sales Consultan/Counter. 


\section{Perancangan Basis Data}

\section{Entity Relationship Diagram (ERD)}

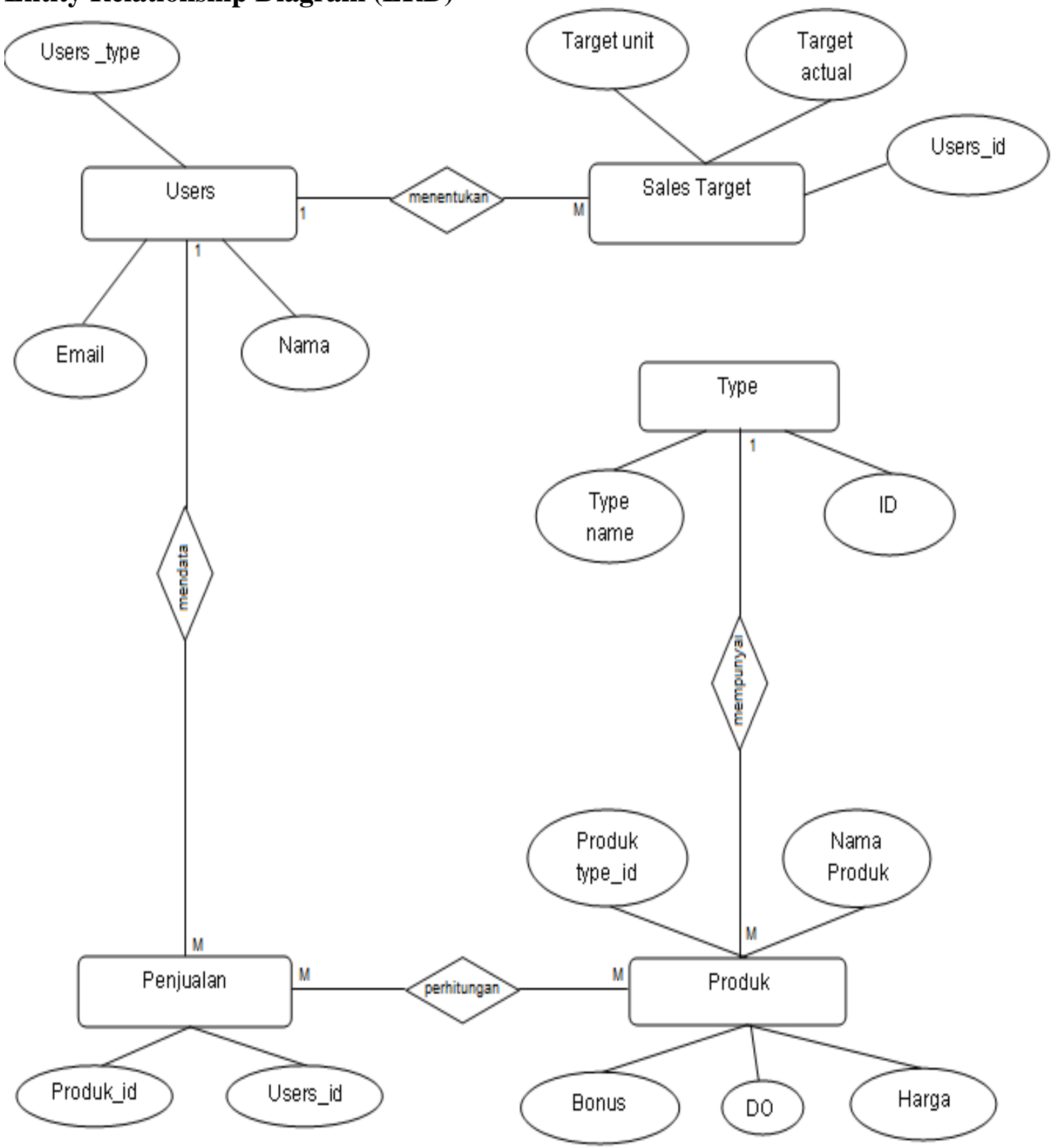

Gambar 3.15. ERD Sistem Informasi Penjualan PT. Lautan Berlian Utama Motor yang diusulkan.

\section{Perancangan Antarmuka}

Perancangan antar muka merupakan perancangan yang dibuat sebelum program aplikasi dibuat, perancangan antar muka pada Sistem Informasi Penjualan Pada PT. Lautan Berlian Utama Motor yang akan dibangun adalah sebagai berikut: 


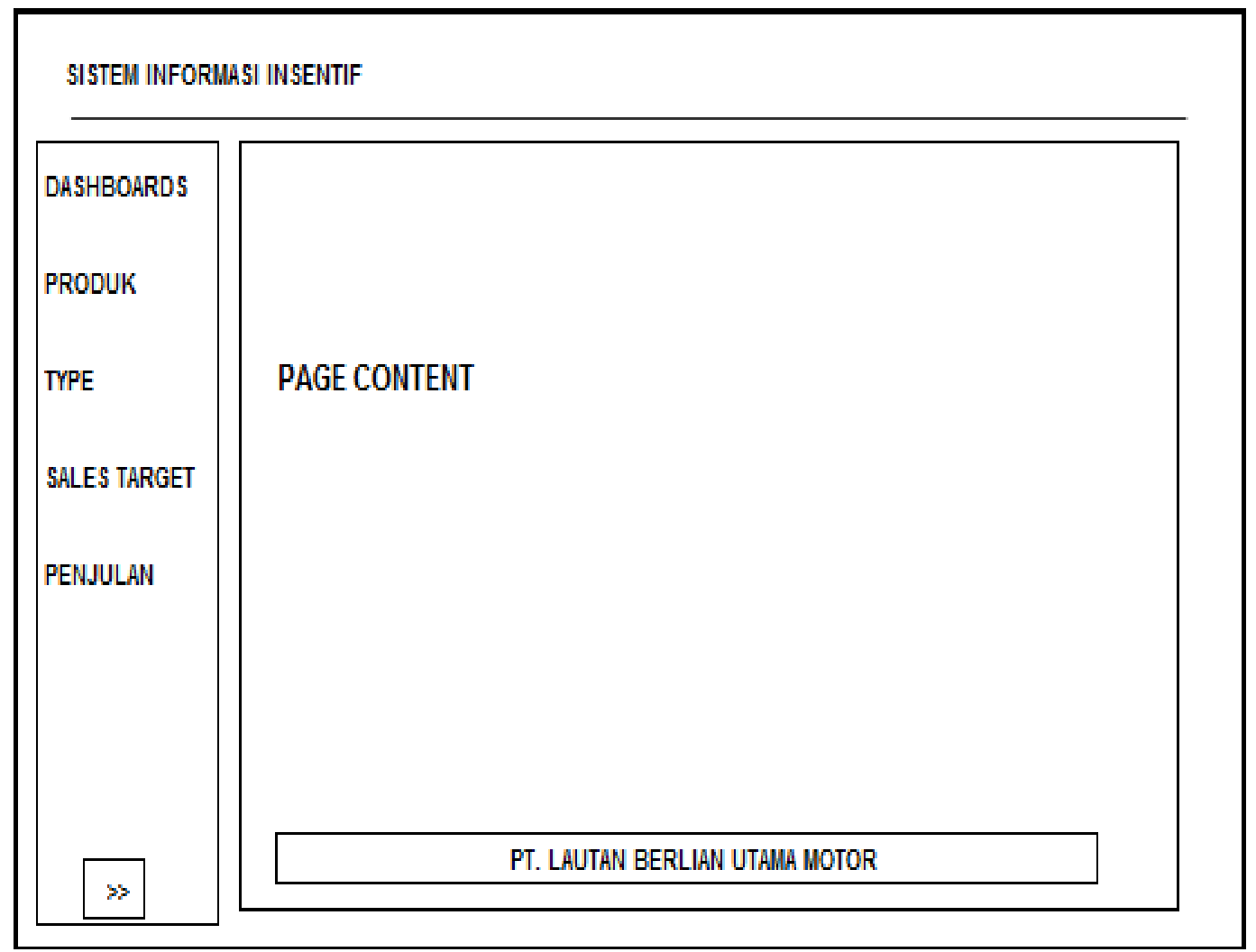

Gambar 3.16 : Rancangan Menu Utama

\section{Perangkat Komputer \\ Perangkat Keras}

Perangkat keras (Hardware) yang digunakan adalah seperangkat alat yang dapat membantu sistem yang diusulkan. Kebutuhan minimun perangkat keras yang di perlukan untuk menjalankan aplikasi Sistem Informasi Perhitungan Insentif Sales Consultan/Counter sebagai berikut :

Processor : Intel (R) Coleron (R) CPU $\mathrm{N} 28402.16 \mathrm{GHz}$

RAM : $2.00 \mathrm{~GB}$

HardDisk : 120 GB

Laptop : Lenovo

\section{Perangkat Lunak}

Perangkat lunak (Software) merupakan dalam data processing system yang berupa program - program atau instruksi - instruksi yang diperlukan dalam menjalankan perangkat keras. Sedangkan untuk Software yang di gunakan dalam perancangan Sistem Informasi Perhitungan Insentif (Bonus) Sales Consultan/Counter adalah sebagai berikut :

1. Sistem Operasi menggunakan Microsoft Windows 8.

2. Database pengolahan data mengunakan XAMPP MySQL.

3. Untuk menampilkan aplikasi menggunakan browser Mozila Firefox.

4. Untuk perancangan desain sistem menggunakan Power Designer 15.2.

5. Untuk dokumentasi menggunakan Microsoft Office Word 2007.

\section{Pengujian System}

Uji coba sistem dilakukan pada saat semua sistem yang diperlukan sudah terpenuhi agar sistem dapat dijalankan dengan baik sesuai dengan analisis yang telah dilakukan. 


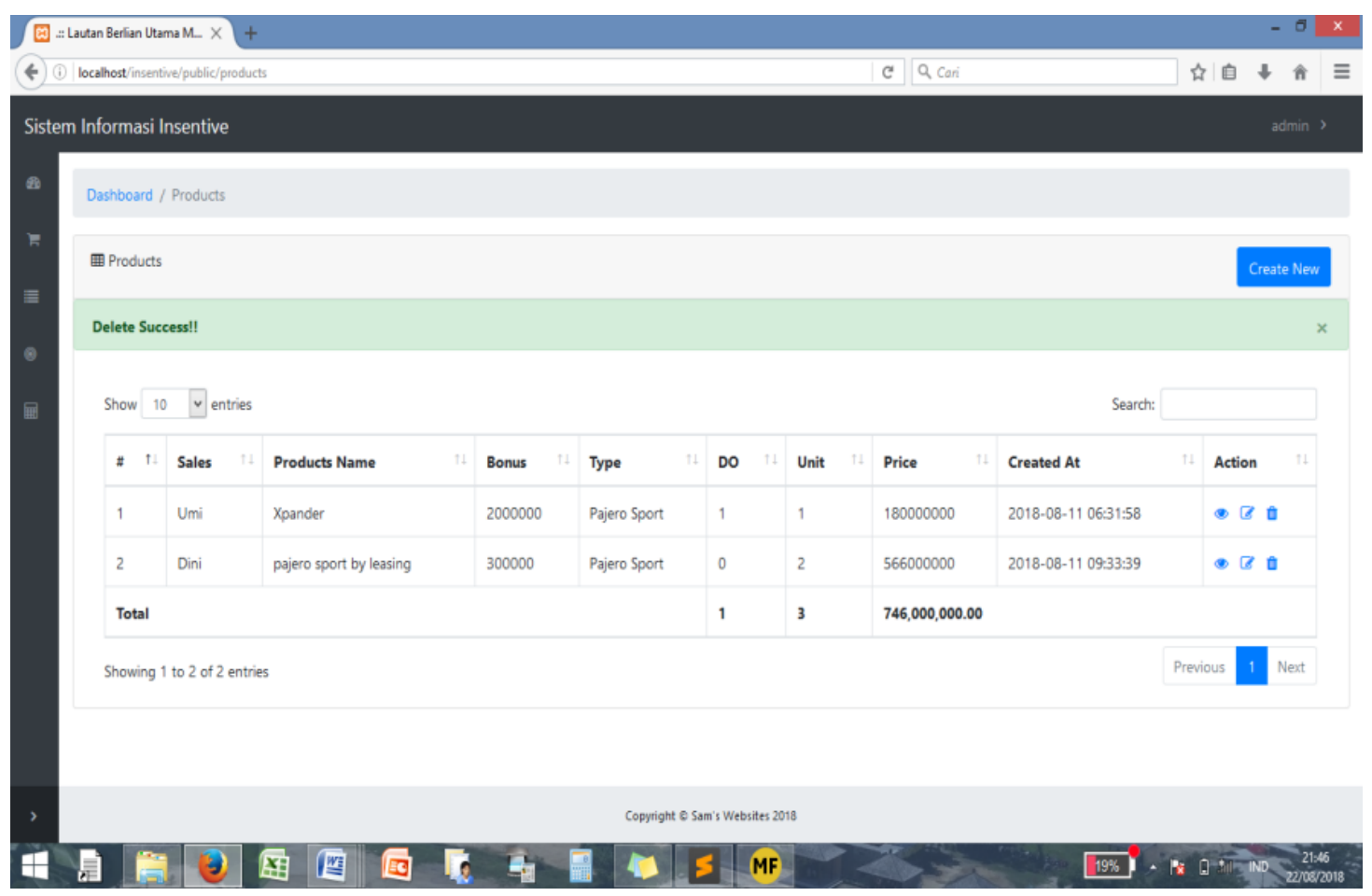

Gambar 4.1 Halaman Dashboard

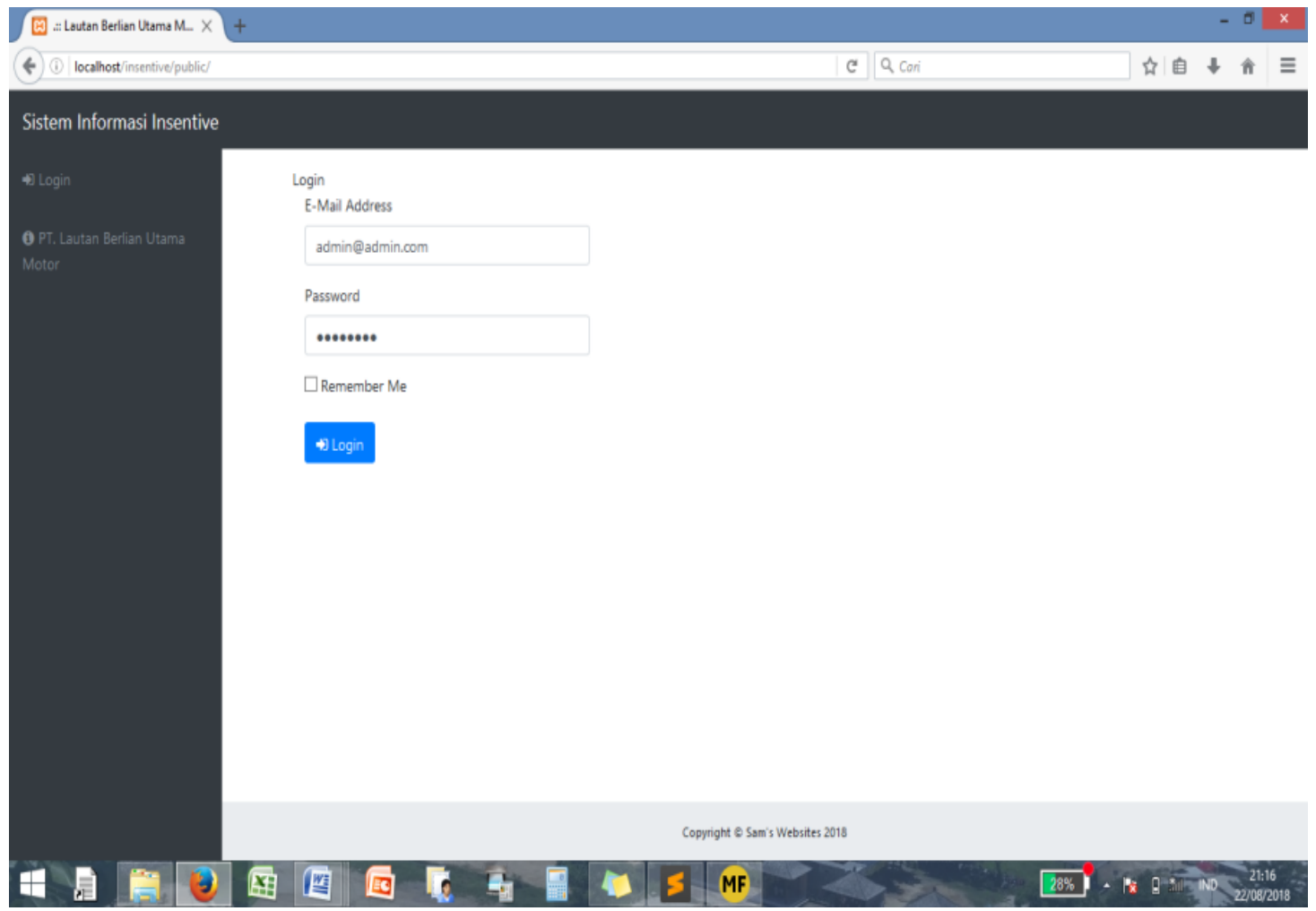

Gambar 4.2 Halaman Login 


\section{PENUTUP}

\section{Kesimpulan}

Berdasarkan implementasi dan hasil evaluasi yang telah dilakukan, maka dapat di simpulkan bahwa :

1) Sistem Informasi ini dapat berguna untuk mengelola data secara akurat dan meminimalisir terjadinya human error pada perhitungan insentif (bonus) sales consultan/counter yang terjadi pada PT. Lautan Berlian Utama Motor.

2) Sistem informasi ini dapat menghasilkan penyimpanan data, laporan penjualan produk, dan laporan nilai perhitungan insentif yang nantinya akan memudahkan sales consultan/counter dalam proses pencairan insentif dan sebagai landasan untuk mengambil keputusan dengan baik.

3) $\mathrm{Di}$ dalam sistem informasi perhitungan insentif sales consultan/counter terdapat uji coba sistem, dan kuesioner. Dengan hasil "Sangat Memuaskan" Sistem informasi ini dapat memenuhi kebutuhan di PT. Lautan Berlian Utama Motor.

\section{Saran}

Saran yang dapat disampaikan dalam Perancangan Sistem Informasi Perhitungan Insentif (Bonus) Sales Consultan/Counter pada PT. Lautan Berlian Utama Motor, yaitu :

1) Sistem Informasi perhitungan insentif sales ini dapat di kembangkan ke dalam aplikasi mobile berbasis android, ios sehingga dapat memudahkan sales counter untuk melihat total nilai insentif yang di dapat.

2) Meningkatkan keamanan dan jaringan pada PT. Lautan Berlian Utama Motor sehingga website ini dapat berjalan secara online

3) Memperbesar kapasitas server untuk penyimpanan database dalam jangka waktu yg lama mengenai data - data, laporan - laporan yang berhubungan dengan perhitungan insentif (bonus)sales.

\section{DAFTAR PUSTAKA}

Abdul Kadir, 2003, Pengenalan Sistem Informasi, Yogyakarta : Penerbit Andi Yogyakarta. Adi. Nugroho, 2010. Rekayasa Perangkat Lunak Berbasis Objek dengan Metode. USDP.Andi Yogyakarta

Ariesto Hadi Sutopo, 2012, Teknologi Informasi Dan Komunikasi Dalam Pendidikan, Edisi Pertama, Yogyakarta; Graha Ilmu.

Edhy Susanto, 2003, Sistem Informasi Manajemen, Yogyakarta : Penerbit Graha Ilmu.

Henderi. 2008. Unified Modeling Language, Herlawati, Prabowo Pudjo Widodo. 2011. Menggunakan UML. Bandung : Informatika.

Raymond McLeod, Jr. 2003 Sistem Informasi Edisi 7 Jilid 2. Prenhallindo Jakarta 
